\title{
Review \\ Self-Sterilizing Sputtered Films for Applications in Hospital Facilities
}

\author{
Sami Rtimi * (D), Stefanos Giannakis (D) and Cesar Pulgarin * \\ Group of Advanced Oxidation Processes, Swiss Federal Institute of Technology, EPFL-SB-ISIC-GPAO, \\ Station 6, CH-1015 Lausanne, Switzerland; stefanos.giannakis@epfl.ch \\ * Correspondence: sami.rtimi@epfl.com (S.R.); cesar.pulgarin@epfl.ch (C.P.); Tel.: +41-216-936-150 (S.R.)
}

Received: 4 May 2017; Accepted: 23 May 2017; Published: 28 June 2017

\begin{abstract}
This review addresses the preparation of antibacterial 2D textile and thin polymer films and 3D surfaces like catheters for applications in hospital and health care facilities. The sputtering of films applying different levels of energy led to the deposition of metal/oxide/composite/films showing differentiated antibacterial kinetics and surface microstructure. The optimization of the film composition in regards to the antibacterial active component was carried out in each case to attain the fastest antibacterial kinetics, since this is essential when designing films avoiding biofilm formation (under light and in the dark). The antimicrobial performance of these sputtered films on Staphylococcus aureus (MRSA) and Escherichia coli (E. coli) were tested. A protecting effect of $\mathrm{TiO}_{2}$ was found for the release of $\mathrm{Cu}$ by the $\mathrm{TiO}_{2}-\mathrm{Cu}$ films compared to films sputtered by $\mathrm{Cu}$ only. The $\mathrm{Cu}$-released during bacterial inactivation by $\mathrm{TiO}_{2}-\mathrm{Cu}$ was observed to be much lower compared to the films sputtered only by $\mathrm{Cu}$. The $\mathrm{FeOx}-\mathrm{TiO}_{2}-\mathrm{PE}$ films induced $E$. coli inactivation under solar or under visible light with a similar inactivation kinetics, confirming the predominant role of $\mathrm{FeOx}$ in these composite films. By up-to-date surface science techniques were used to characterize the surface properties of the sputtered films. A mechanism of bacteria inactivation is suggested for each particular film consistent with the experimental results found and compared with the literature.
\end{abstract}

Keywords: antibacterial surfaces; light; metal oxides; coatings; magnetron sputtering

\section{Introduction}

Hospital acquired infections (HAIs) are on the rise in Europe, infecting $5-7 \%$ of hospital patients staying beyond 10 days with the consequent high cost related to the long and costly hospital residence time [1]. Thirty years ago, Domek et al. [2] reported the inactivation of coliform bacteria by $\mathrm{Cu}$, later Keevil's group reported the $\mathrm{Cu}$ inactivation of MRSA [3] and E. coli [4]. The Cu-ions released from coated surfaces were reported to induce a strong biocidal effect below the cytotoxic levels accepted for mammalian cells. This consideration validates the use of $\mathrm{Cu}$-immobilized devices in bloodstream infections [5]. The disinfection in some cases seems to proceed via an oligodynamic effect due to the low amounts (in the ppb/ppm range) of $\mathrm{Cu}$ or Ag released by these surfaces [6]. Cu-ions have been shown to complex proteins and break hydrogen bonds within the DNA opening the double helix [7].

Antimicrobial coatings are being investigated to prepare implants and medical devices [8-11]. Recently, research groups reported Chemical Vapor Deposition (CVD) of Cu-titania films being applied in single or multilayered coatings [8-13]. Innovative films against MRSA infections have been recently reported for packaging materials [14], plastics [15] and stethoscopes [16]. Boyce et al. [17] found MRSA contamination up to $65 \%$ in the hospital staff gloves and uniforms due to the contact in hospital-infected rooms/surfaces. Later, Bhalla et al. [18] showed that hospital workers frequently had infected gloves/uniforms in variable concentrations with the bacteria/fungi available in the hospital facilities. Bacteria invade, adhere and form biofilms that tightly glue to the surface (catheters or other 
medical devices) [19]. For this reason, biofilm formation has to be precluded. Catheters impregnated with antibiotics/antiseptics or both showed a short-term effect lasting only a few days. This is due to the rapid release of the antibacterial agent. This complicated in hospital settings by the increased bacterial resistance to many antibiotics affecting patients during long-hospital residence times [20,21].

Studies have shown rapid killing of bacterial cells when exposed to $\mathrm{Cu}$-surfaces but the mechanism of the Cu-MRSA killing is still controversial [6-13]. The Cu-antimicrobial action seems to comprise the cellular metabolism damaging the cell DNA [22]. A recent study has shown that the uptake of Cu-ions by MRSA was fast and damaged the cell DNA, but the mechanism of this uptake remains controversial and more work is needed in this direction [1,22].

Recently, Heidenau et al. [10,11] demonstrated that in Ag-Cu amalgams, $\mathrm{Cu}$ in extremely low amounts inactivate more effectively bacteria compared to other metals. The Ag-Cu films were found to present surfaces with a high in vitro compatibility. Recent work in our laboratory with Cu-sputtered surfaces induced a faster kinetic bacterial inactivation [23,24] compared to Ag-sputtered surfaces [25,26]. $\mathrm{TiO}_{2}$ surfaces in the dark are ineffective against bacterial infection, but $\mathrm{Cu}-\mathrm{TiO}_{2}$ surfaces introduce antibacterial action in the dark on medical implants $[27,28]$. $\mathrm{TiO}_{2}$ has been reported to increase the adhesion of $\mathrm{Cu}$ on glass and other surfaces avoiding leaching during disinfection and therefore assumes the role of a protective additive hindering the $\mathrm{Cu}$-release.

In the past few years, the continuous exposure to antibiotics over long times has led to increased antibiotic resistance of bacteria. However, only a few pathogens display resistance to $\mathrm{Ag}$ and $\mathrm{Cu}$ and combinations thereof $[1,6,29,30]$. Cu-Ag films show long-operational lifetime, which is not the case for antibiotics/antiseptics rapidly detaching from the film surface. This is important when antibacterial films are used in connection to bloodstream. In this review, we focus on the preparation of innovative antibacterial coatings on 2D surfaces (polyethylene or polyurethane films) and on 3D complex shape medical devices (intravascular catheters). The sputtering of uniform, adhesive coatings with $\mathrm{Cu}$ and Ag on low thermal resistant fabrics like hospital textiles and thin polymer films are reviewed as well as material related to $\mathrm{TiO}_{2}, \mathrm{TiO}_{2}-\mathrm{Cu}$ (both on polyester), $\mathrm{FeOx}$ and $\mathrm{FeOx}-\mathrm{TiO}_{2}$ (both on polyethylene films) [30-35].

\section{Antibacterial Coatings: From Conventional to up to Date Methods}

Conventional deposition techniques e.g., sol-gel or films prepared via the colloidal route enable the synthesis of materials with a high thermal resistance since a temperature of a few hundred degrees has to be applied to anneal the active antibacterial component to the particular substrate. Commercial sol-gel methods have reported $\mathrm{TiO}_{2}$ and other thin films on heat resistant substrates [35].

Photo-induced reactions by finely dispersed Ag-nanoparticles (Ag-NPs) of $\sim 2 \mathrm{~nm}$ in size have been reported to inactivate E. coli and Staphylococcus aureus. This dispersion also showed photo-switchable behavior involving a transition from an initial hydrophobic surface towards a super-hydrophilic surface within the bacterial inactivation time under light irradiation. The contact angle (and surface energies) was followed under light and in the dark. The reversible process to reestablish the initial hydrophobicity (dark storage of the sample after bacterial inactivation under light) was seen to happen within long times (>24 h) [35].

Estimates for the effective bacteria reduction by Ag-coated surfaces suggest that these may be able to reduce the contamination in hospitals and public places [36-39]. The level found for these bacteria in many hospitals is higher than the allowed level for the healthcare rooms. For example, the contamination of $10^{5} \mathrm{CFU} / \mathrm{cm}^{2}$ was observed in a diabetic wound dressing. Nevertheless, near the patient, a microbial density of about $10^{2} \mathrm{CFU} / \mathrm{cm}^{2}$ was found. The use of catalytic/photocatalytic textiles (for beddings, curtains, lab-coats ... ) can drastically decrease the bacterial propagation [38-42].

The major limitations towards the use of sol-gel photoactive surfaces are related to (i) the lack of uniformity of these sol-gel films; (ii) the non-reproducible preparation observed from different batches with the same composition and (iii) the lack of mechanical stability and adhesion to the 
substrate $[24-26,40]$. The sputtering methods described in this review have been applied to obtain robust antibacterial films on cotton, polyester, polyethylene and polyurethane thin films $[34,35,40]$.

During the last four decades, the sputtering of surfaces for industries in the aviation, car and machine tool sectors was used to protect the surfaces against corrosion by sputtering micrometer thick coatings of $\mathrm{Cr}$-Fe to avoid the corrosion of the $\mathrm{Fe} / \mathrm{Fe}_{2} \mathrm{O}_{3}$ layers. Nowadays, thin coatings are used for many purposes such as to avoid surface corrosion, to serve as anti-reflective and to acquire self-cleaning and self-sterilizing properties. Recently sputtering in the presence of $\mathrm{O}_{2}$ have been carried out to deposit thin metal oxides on non-heat resistant substrates like textiles at temperatures $<130$ ${ }^{\circ} \mathrm{C}$ by DCMS, DCPMS [41] and HIPIMS [42]. During the last decade, Kelly et al. has addressed the preparation of antibacterial thin films by magnetron sputtering (DCMS, DCMP and HIPIMS). They characterized the film surface properties and corrosion and correlated with the antibacterial activities [43-46]. Several recent studies report that the antibacterial activity of metal/oxide films is a function of the dispersion, size and thickness of the metal/oxide coatings [5,8,12,13,30,44,46-50]. Diverse thicknesses in the $\mathrm{TiO}_{2}$ coatings led to a complete different $\mathrm{Cu}$-dispersion, $\mathrm{Cu}$ nanoparticulate size and bacterial inactivation kinetics as recently reported [12,29,40,49,51,58]. During the last years, we investigated the bactericidal activity on $\mathrm{Ag}, \mathrm{Cu}$, and other metal oxides sputtered on polymers and textile fabrics. The antibacterial kinetics, microstructure and surface properties have been reported in details [40-42,50-53].

\section{Photocatalytic Coated Polyester Showing Duality in the E. coli and MRSA Inactivation under Actinic Indoor Light}

Recently, some laboratories have reported the preparation of antibacterial $\mathrm{Ag}, \mathrm{Cu}$ and $\mathrm{TiO}_{2}$ coatings on glass and polymer films by depositing the metal/oxides by CVD and sputtering techniques $[8,29,30,32,44-46]$. The direct current magnetron sputtering (DCMS) co-deposition of $\mathrm{TiO}_{2}$ and $\mathrm{Cu}$ films leading to uniform, adhesive and robust layers on polyester (PES) at temperatures not exceeding $120-130{ }^{\circ} \mathrm{C}$ has been reported recently [29,30]. There is a need for innovative active coatings showing a fast bacterial inactivation kinetics and a high adhesion to the substrate. In this way, the formation of toxic biofilms spreading bacteria/virus/fungi in hospital facilities leading to increased HAIs may be precluded.

Recent studies report the preparation of $\mathrm{TiO}_{2}, \mathrm{Cu}$ and $\mathrm{TiO}_{2} / \mathrm{Cu}$ films by sol-gel methods inducing significant photo-induced bacterial inactivation of films deposited on glass surfaces from Ti-chloride/ethyl acetate annealed at $500{ }^{\circ} \mathrm{C}$ [40,47-50]. Our laboratory has reported Escherichia coli (E. coli) inactivation on $\mathrm{TiO}_{2} / \mathrm{Cu}$ sequentially sputtered (deposited one after the other starting with an under layer of $\mathrm{TiO}_{2}$ then an upper layer of $\mathrm{Cu} / \mathrm{CuOx}$ ). Moreover, the co-sputtering of $\mathrm{TiO}_{2}-\mathrm{Cu}$ (simultaneous deposition) on textiles leading to E. coli and methicillin-resistant Staphylococcus aureus (MRSA) reduction was reported [43]. The later reports the differential effect of actinic and visible light $(400-700 \mathrm{~nm})$ on the bacterial reduction kinetics on E. coli as a MRSA.

The $\mathrm{TiO}_{2}$-Cu-PES microstructure is shown by TEM in Figure 1. The denser $\mathrm{Cu}$-clusters presented diameters between 16 and $20 \mathrm{~nm}$ while the $\mathrm{TiO}_{2}$ clusters presented smaller sizes from 5 and up to $10 \mathrm{~nm}$. The $\mathrm{TiO}_{2}-\mathrm{Cu}$ coatings were 120 to $160 \mathrm{~nm}$ thick. This is equivalent to 500 to 800 atomic layers (being each layer $0.2 \mathrm{~nm}$ thick) each containing $10^{15}$ atoms $/ \mathrm{cm}^{2}$ [51]. It showed close contact between the $\mathrm{TiO}_{2}$ and $\mathrm{Cu}$-nanoparticles and was uniform in its microstructure $[32,35,50]$.

The bacterial inactivation by $\mathrm{TiO}_{2}$-Cu-PES under actinic light irradiation and in the dark was evaluated as a function of the amount of $\mathrm{TiO}_{2}$ and $\mathrm{Cu}$ sputtered on the substrate [41]. The deposition time of $\mathrm{TiO}_{2}-\mathrm{Cu}$ (co-sputtering) was optimized to determine the most suitable amount of $\mathrm{TiO}_{2}$ and $\mathrm{Cu}$ on the inactivating E. coli. In the dark, E. coli bacterial inactivation proceeds within $120 \mathrm{~min}$ on $\mathrm{TiO}_{2}$-Cu-PES. The mechanism of $\mathrm{TiO}_{2}-\mathrm{Cu}(\mathrm{CuO})$ mediated E. coli inactivation under light irradiation has been reported to involve interfacial charge transfer (IFCT) [29,40]. Bacterial reduction in the dark as shown in Figure 2, trace 6) and seems to proceed through a mechanism where $\mathrm{O}_{2}$ (air) reacts with the $\mathrm{Cu}^{0} / \mathrm{Cu}$-ions. Figure 2, trace 1) shows the complete bacterial reduction under visible light within 
$30 \mathrm{~min}$ for $\mathrm{TiO}_{2}-\mathrm{Cu}$ samples co-sputtered for $3 \mathrm{~min}$. Within $3 \mathrm{~min}$, a sufficient amount of $\mathrm{TiO}_{2}$ and $\mathrm{Cu}$ was sputtered on the PES leading to the most suitable number of exposed catalytic sites leading to the fastest $E$. coli inactivation.

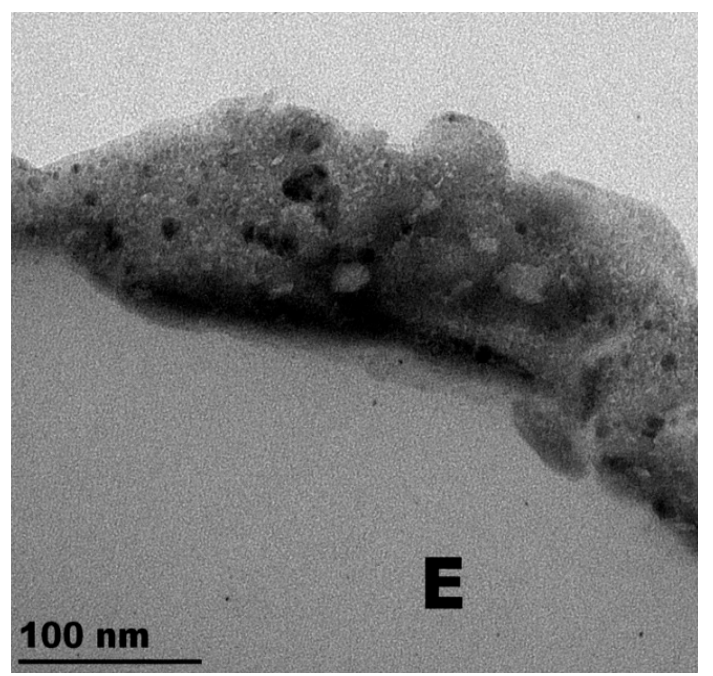

Figure 1. Transmission electron microscopy (TEM) of $\mathrm{TiO}_{2}$-Cu co-sputtered for 3 min on PES. "E" stands for the epoxide required to embed the sample during the sample preparation/cutting for the TEM image [32].

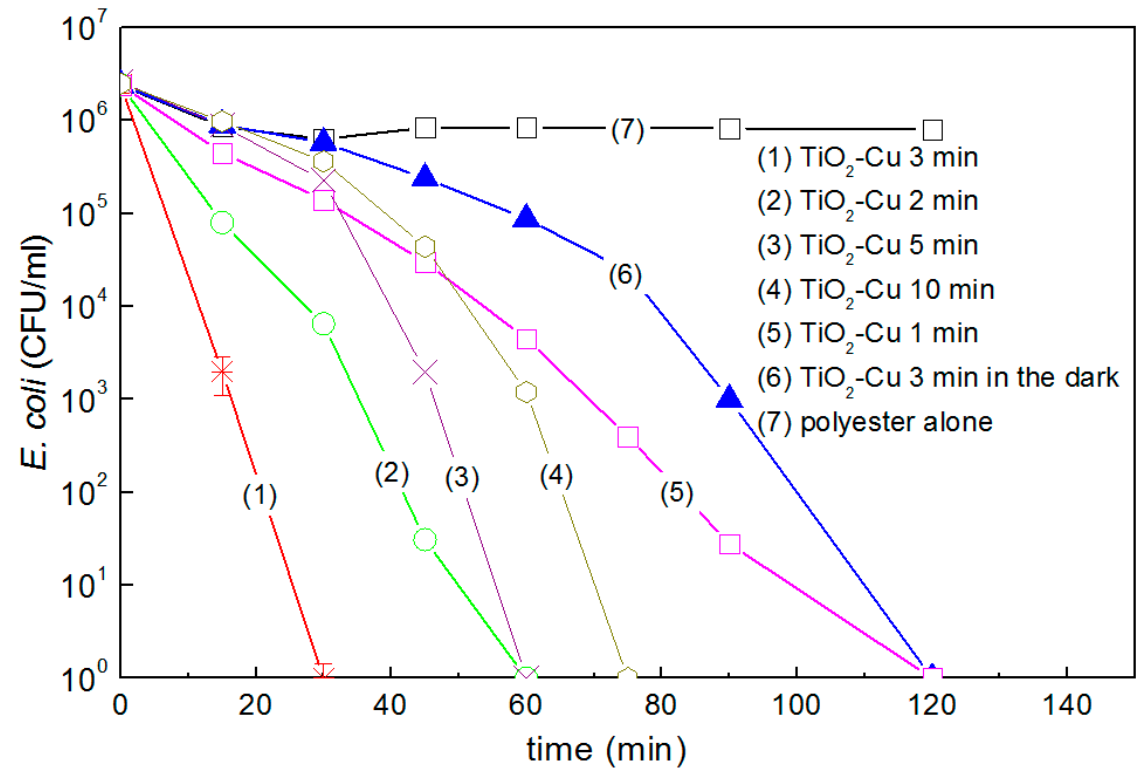

Figure 2. E. coli inactivation on $\mathrm{TiO}_{2}-\mathrm{Cu}$ co-sputtered for different times on PES as indicated in the traces: (1) $3 \mathrm{~min}$, (2) $2 \mathrm{~min}$, (3) $5 \mathrm{~min}$, (4) $10 \mathrm{~min}$, (5) $1 \mathrm{~min}$ (6) $3 \mathrm{~min}$ in the dark and (7) PES-alone. The bacterial reduction under light irradiation used a lamp Philips Master-18W/865 (4.65 mW/ $\left.\mathrm{cm}^{2}\right)$, Error bars: standard deviation $(n=5 \%)$.

Co-sputtering for short times (1-2 min) did not deposit the necessary amount of $\mathrm{TiO}_{2}$ and $\mathrm{Cu}$ to induce a fast bacterial inactivation. Co-sputtering $\mathrm{TiO}_{2}-\mathrm{Cu}$ for 5 and $10 \mathrm{~min}$ (Figure 2) led to longer bacterial inactivation kinetics compared to $\mathrm{TiO}_{2}-\mathrm{Cu}(3 \mathrm{~min})$. This is due to the inward charge diffusion of the generated charges in the $\mathrm{TiO}_{2}$ under band-gap irradiation [29,51]. In addition, longer sputtering times facilitate the $\mathrm{TiO}_{2}$ inter-particle growth decreasing the $\mathrm{TiO}_{2}$ contact surface with bacteria [52]. Figure 2, trace 6) shows complete bacterial reduction in the dark. Bacterial inactivation takes place in 
the dark possibly through an oligodynamic effect as recently reported by S. Rtimi $[41,52,53]$. The effect of $\mathrm{Cu}$ on bacteria has been associated to reactions blocking the of proteins/enzymes regulating the respiratory chain $[32,41,52]$.

The electronic transfer between the $\mathrm{TiO}_{2} / \mathrm{Cu}$ and E. coli depends on the length of the charge diffusion in the $\mathrm{TiO}_{2} / \mathrm{Cu}$ layers. The diffusion of the charges induced by band-gap irradiation is a function of the $\mathrm{TiO}_{2}$ and $\mathrm{Cu}$ particle size and shape [54,55]. The interfacial distances between $\mathrm{TiO}_{2}$ and $\mathrm{Cu} / \mathrm{CuO}$ on the polyester surface ranges from $5 \mathrm{~nm}$ and up. The IFCT, as shown in Figure 2, proceeds with a quantum efficiency depending on the light intensity and the nanoparticulate size [56-58]. Quantum size effects occur in particles with sizes $\sim 10 \mathrm{~nm}$ and about $10^{4}$ atoms or smaller [59]. The surface composition and properties of the $\mathrm{TiO}_{2}-\mathrm{CuO}$ play a role in the charge transfer. The bacterial inactivation kinetics depends on the film (i) surface defects; (ii) surface imperfections; and (iii) dangling bonds on the edge of this composite. $\mathrm{In} \mathrm{TiO}_{2}-\mathrm{Cu}$ composite, the charge recombination in nanoparticles is short due to their small particle size. The small particle size decreases the space for charge separation. In addition, the semiconductor space charge layer in both the $\mathrm{TiO}_{2}$ and $\mathrm{CuO}$ further decreases the potential depth available for the charge injection at the $\mathrm{TiO}_{2}-\mathrm{Cu}$ hetero-junction. This in turn, decreases the energy difference between $\mathrm{TiO}_{2}$ and $\mathrm{Cu}$, which is not favorable for the charge injection $[29,52]$. The conduction band of $\mathrm{CuO}$ at $-0.30 \mathrm{~V}$ vs. SCE $(\mathrm{pH} 7)$ is at a more negative potential than the potential required for one electron oxygen reduction [52]. Furthermore, the $\mathrm{Cu}^{2+}$ can also react with $\mathrm{O}_{2}^{-}$:

$$
\begin{gathered}
\mathrm{O}_{2}+\mathrm{H}^{+}+\mathrm{e}^{-} \rightarrow \mathrm{HO}_{2}^{\bullet}-0.22 \mathrm{~V} \\
\mathrm{Cu}^{2+}+\mathrm{O}_{2}^{-} \rightarrow \mathrm{Cu}^{+}+\mathrm{O}_{2}
\end{gathered}
$$

The irradiation with solar simulated light induces the transfer of the $\mathrm{e}^{-}$and $\mathrm{h}^{+}$from $\mathrm{TiO}_{2}$ to $\mathrm{CuO}$ as shown in Figure 3 below. Charge transfer from ad-atoms to $\mathrm{TiO}_{2}$ under light has been investigated during the last few decades [40]. The potential energy levels of the $\mathrm{TiO}_{2}$ conduction band (cb) and $\mathrm{TiO}_{2}$ valence band $(\mathrm{vb})$ lie above the $\mathrm{CuO}(\mathrm{cb})$ and $\mathrm{CuO}(\mathrm{vb})$ as shown in Figure 3. The partial recombination of $\mathrm{e}^{-} / \mathrm{h}^{+}$in $\mathrm{TiO}_{2}$ is hindered by the charge injection into $\mathrm{CuO}$. The interfacial charge transfer (IFCT) between the $\mathrm{TiO}_{2}$ and the $\mathrm{CuO}(\mathrm{vb})$ of $+1.4 \mathrm{eV}$ to the $\mathrm{TiO}_{2}(\mathrm{vb})$ at $2.5 \mathrm{eV}$ vs. SCE, $\mathrm{pH} 0$, and proceeds with a considerable driving force due to the large potential energy difference between these two valence band levels.

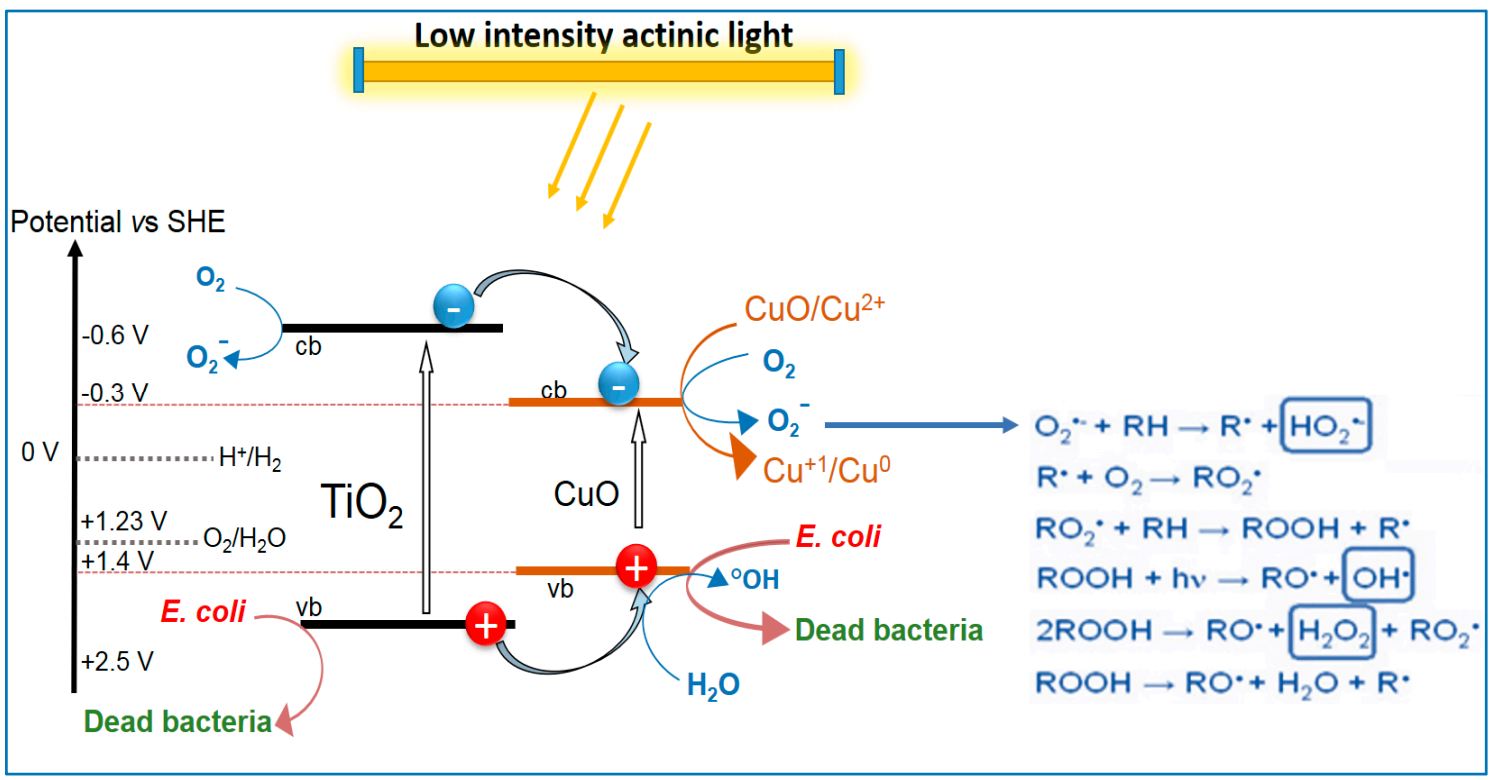

Figure 3. Diagram suggested for of bacterial inactivation under solar simulated light photocatalyzed by $\mathrm{TiO}_{2} / \mathrm{Cu}$ films sputtered on polyester (PES) [52]. 
A model for the charge transfer between $\mathrm{TiO}_{2}$ and $\mathrm{CuO}$ under solar light (UV-Vis) has been suggested [40,52] with respect to previous reports [56-58] and presented in Figure 3. The E. coli inactivation proceeded within a few minutes $[29,52]$. These $\mathrm{TiO}_{2}(\mathrm{vb})$ holes react with the surface-OH groups of the $\mathrm{TiO}_{2}$ releasing $\mathrm{OH}$-radicals. The $\mathrm{CuO}$ nanoparticles on the $\mathrm{TiO}_{2}$ can be reduced to $\mathrm{Cu}_{2} \mathrm{O}$ by the charges generated in the $\mathrm{TiO}_{2}$ under light and can later re-oxidize to $\mathrm{CuO}$ as investigated by X-ray photoelectron spectroscopy (XPS) in recent report [52]. The $\mathrm{TiO}_{2} / \mathrm{Cu}$ co-sputtered samples showed that $\mathrm{TiO}_{2}$ plays a stabilizing effect on the $\mathrm{Cu}$-release from the co-sputtered surfaces during bacterial inactivation compared to $\mathrm{Cu}$ deposed individually [29,52]. A low amount of Cu-released in the ppb range inactivated both Gram-positive and Gram-negative bacteria, possibly through an oligodynamic effect as observed in dark runs but needing longer times [53,59].

\section{Nanostructured Fe-Oxides for Self-Sterilizing through an Oligodynamic Effect: Surface Properties}

Iron oxide nanoparticles (NP's) are of considerable interest due to their wide applications in fields such as magnetic storage, medicine, chemical industries, catalytic materials and water purification [60]. The synthesis of $\mathrm{Fe}_{2} \mathrm{O}_{3}, \mathrm{FeO}$ and $\mathrm{Fe}_{3} \mathrm{O}_{4}$ involve routes including precipitation, sol-gel, hydrothermal, dry vapor deposition, has been carried out by way of micro-emulsion, electro-deposition and sonochemistry $[61,62]$.

To avoid the time, work and reagents needed to separate the products from reactions catalyzed by suspensions at the end of water detoxification processes involving nanoparticles, metal/metal oxide coatings were prepared. Polymer-based films have been applied in protective coatings of medical devices [63,64], thin-films and bactericide/self-cleaning surfaces [64-66]. Films grafted by colloids weakly adhered to the substrate, have shown to be not entirely reproducible and can be wiped out of the polymer surface $[49,66,67]$.

Polyethylene (PE) thin film is a flexible low cost polymer resistant to corrosion and withstands up to $120{ }^{\circ} \mathrm{C}$ for short times were coated/sputtered with FeOx [49,68]. Due to its low surface energy, the PE limits the adhesion of particles on its surface. In order to bind a higher amount of catalytic species on the PE surface suitable anchor groups have been used to attain acceptable catalysts loadings leading to the degradation of pollutants/bacteria occurring with a satisfactory kinetics. Surface pretreatment was necessary to increase the number of oxidative sites, hydrophilicity, and surface-roughness necessary for better $\mathrm{FeOx}$ bonding [69]. The polyethylene fabrics were pretreated in the cavity of an RF-plasma unit (13.56 MHz, 100 W, Harrick Corp., Ithaca, NY, USA) at a pressure of 1 torr. The topmost PE-layers of $2 \mathrm{~nm}$ ( 10 atomic layers) were RF-plasma pretreated for $15 \mathrm{~min}$. Oxygen RF-produced plasma reacts with the PE surface to induce groups like $\mathrm{C}-\mathrm{O}, \mathrm{C}=\mathrm{O}, \mathrm{O}-\mathrm{C}=\mathrm{O}$, $\mathrm{C}-\mathrm{O}-\mathrm{O}-$ on the PE surface. This pretreatment introduces hydrophilic groups on the PE-surface and breaks the intermolecular PE- and the $\mathrm{H}-\mathrm{H}$ bonds segmenting the PE-fibers [35,70]. The slightly positive FeOx binds the negatively charged pretreated PE (containing the overall negative carboxylic groups) through electrostatic interaction and chelation/complexation [68]. FeOx was sputtered from a target $5 \mathrm{~cm}$ diameter (Kurt Lesker, East Sussex, UK) positioned at $10 \mathrm{~cm}$ from the target by direct current magnetron sputtering (DCMS) on PE. The PE consists of highly branched low crystalline semi-transparent film with the formula $\mathrm{H}\left(\mathrm{CH}_{2}-\mathrm{CH}_{2}\right)_{n} \mathrm{H}$ (ET3112019, Goodfellow, Huntingdon, UK). The PE-FeOx mediated bacterial reduction was determined on Escherichia coli (E. coli K12 ATCC23716) on $2 \mathrm{~cm}$ by $2 \mathrm{~cm}$ PE-FeOx samples under solar simulated light $\left(52 \mathrm{~mW} / \mathrm{cm}^{2}, \sim 0.8 \times 10^{16}\right.$ photons $\left./ \mathrm{s}\right)$ for utilization in environmental cleaning [68,71].

Bacterial inactivation under low intensity solar simulated light on PE-FeOx sputtered films in $\mathrm{Ar}+\mathrm{O}_{2}$ atmosphere proceeded with an acceptable kinetics [68]. The PE-FeOx films avoid the use of heavy metals whose discharge into the environment is not desired or admissible by pertinent sanitary regulations. The bacterial inactivation kinetics was attributed to the redox processes occurring on the surface. The regeneration of the surface initial catalytic states was reported to happen by simply washing the surface with $\mathrm{NaOH}$. The $\mathrm{PE}-\mathrm{FeOx}$ properties like surface polarity, roughness and stability 
were described in details [68,71]. Figure 4 presents the E. coli inactivation under solar simulated light irradiation for PE-samples pretreated with Rf-plasma and Fe-sputtered between $30 \mathrm{~s}$ and $150 \mathrm{~s}$. It is readily seen that Fe-sputtering for $60 \mathrm{~s}$ (trace 1) led to the faster bacterial reduction time. The FeOx film thickness (42 nm equivalent to 210 atomic layers) led to the shortest bacterial reduction time [68]. If one atomic layer is $\sim 0.2 \mathrm{~nm}$ thick and including $10^{15}$ atoms $/ \mathrm{cm}^{2}$, the Fe deposition rate can be estimated as $3.5 \times 10^{15}$ atoms $/ \mathrm{cm}^{2} \times \mathrm{s}$. Sputtering for $30 \mathrm{~s}$ (Figure 4, trace 4) did not deposit enough FeOx on the $\mathrm{PE}\left(0.040 \mathrm{wt} \% \mathrm{Fe}_{2} \mathrm{O}_{3} /\right.$ weight $\left.\mathrm{PE}\right)$. The longer bacterial reduction time shown in Figure 4, traces 4 and 5) for samples sputtered for 120 and 150s showing higher loadings $>0.084$ wt $\% \mathrm{Fe}_{2} \mathrm{O}_{3} /$ weight PE. This was probably due to: (i) the increase in layer thickness leading to the bulk inward diffusion of the charge carriers $[59,68]$, (ii) the increased size of the FeOx at longer sputtering times leading to cluster agglomeration $[68,71]$ and (iii) the increase of the Fe-metal content with respect to FeOx. The bacterial reduction on $\mathrm{PE}-\mathrm{FeO}$ films does not proceed like on PE-alone under simulated solar irradiation.

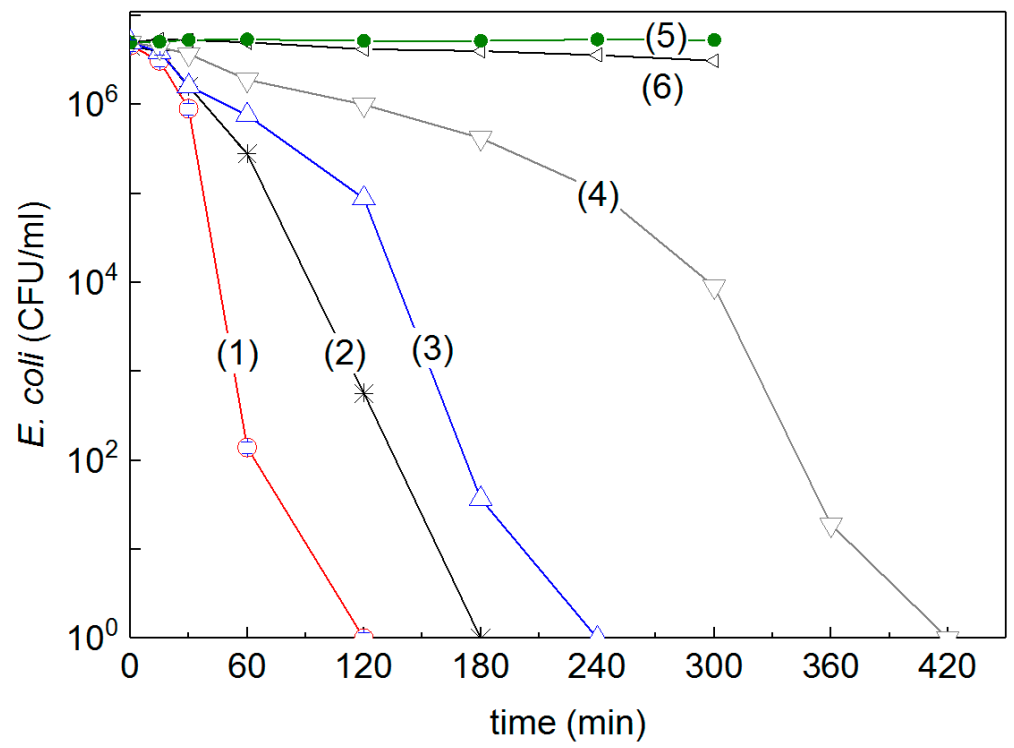

Figure 4. E. coli reduction on PE-FeOx pre-treated surfaces and sputtered for (1) $60 \mathrm{~s}$; (2) $120 \mathrm{~s}$; (3) $150 \mathrm{~s}$; (4) $30 \mathrm{~s}$ and illuminated with solar simulated light of $52 \mathrm{~mW} / \mathrm{cm}^{2}$; (5) PE-FeOx sputtered for $60 \mathrm{~s}$ in the dark and (6) Un-sputtered PE under solar simulated light; Error bars: standard deviation $(n=5 \%)$ [68].

PE-FeOx mediated bacterial reduction was investigated and remained stable up to five cycles (one cycle $=$ one bacterial inactivation run + one water washing run) [68]. The Fe-leached out in ppb amounts during $E$. coli bacterial reduction was determined by inductively coupled mass spectrometry (ICP-MS) and showed a small release of Fe-ions to the environment at below toxicity levels. PE-FeOx induced stable re-cycling during bacterial inactivation trials [68]. Evidence of ppb amounts of Fe was observed in the PE-FeOx mediated bacterial inactivation suggesting an oligodynamic effect. Until now, only heavy meals as $\mathrm{Ag}, \mathrm{Pt}$ and $\mathrm{Pd}$ have been reported to induce bacterial inactivation through the oligodynamic effect, but, this introduces undesirable/detrimental metals into the environment [53]. $\mathrm{Fe}_{2} \mathrm{O}_{3}$ colloids have been reported to leach consistent amounts of Fe during the degradation of pollutants in aqueous suspensions. $\mathrm{Fe}_{2} \mathrm{O}_{3}$ is a stable n-type semiconductor responding to visible light up to $500 \mathrm{~nm}$ with a band-gap of $2.2 \mathrm{eV}$ able to separate the electrons at a potential $\sim 0.1 \mathrm{eV}$ and holes at $\sim 2.3 \mathrm{eV}$ as a function of the applied light ( $\mathrm{pH} 6-7$ ) [68].

By XPS analysis, the PE-FeOx surface atomic concentration and the changes in the Fe-oxidation states during the bacterial inactivation period were followed. The initial Fe(III) in $\mathrm{Fe}_{2} \mathrm{O}_{3}$ at $712.2 \mathrm{eV}$ decreases from $80.0 \%$ (time zero) to $53.0 \%$ after the disinfection period. Fe in the form of $\mathrm{Fe}_{3} \mathrm{O}_{4}$ at $713.6 \mathrm{eV}$ and $\mathrm{Fe}$ (II) with peaks at $709.7 \mathrm{eV}$ was detected before the bacterial disinfection [68]. After disinfection, Fe(III), FeO(II/III) and Fe(II) peaks were: 711.4, 708.6 and 713.8 eV, respectively. 
These changes point out to the shift in the oxidation states in the Fe-oxides during bacterial reduction. The catalysis deriving the bacterial reduction contains three different $\mathrm{FeO}_{x}$ oxide species each one offering a different potential couple and its own surface potential (eigenvalue). The high turnover of the biological material on the photocatalyst surface avoids the accumulation of residual intermediates during bacterial inactivation as observed for the lack of $\mathrm{C} 1 \mathrm{~s}$ and $\mathrm{N} 2 \mathrm{p}$ peaks after the bacterial inactivation on the PE-FeOx surface [68,70].

The electrostatic attraction between the bacteria and PE-FeOx is a dominant effect at distances below four Angstroms, polarizing strongly the interaction between the PE-FeOx within this short distance. A mechanism of reaction was recently suggested taking into consideration the bacterial inactivation dynamics and Equations (3)-(6) below. The generation of highly oxidative radicals (ROS) by the $\mathrm{O}_{2}$ (air) reduction under the solar simulated light was observed concomitantly to the $\mathrm{Fe}(\mathrm{III}) / \mathrm{Fe}(\mathrm{II})$ reduction during bacterial oxidation leading to $\mathrm{CO}_{2}$ and a small amount of mineral trace residues:

$$
\mathrm{Fe}_{2} \mathrm{O}_{3}\left(\mathrm{Fe}^{2+}\right)+\mathrm{O}_{2} \text { (air) }+\mathrm{H}^{+} \rightarrow \mathrm{Fe}_{2} \mathrm{O}_{3}\left(\mathrm{Fe}^{3+}\right)+\mathrm{HO}_{2} \text { • }
$$

The $\mathrm{HO}_{2} \bullet$ radical would convert to $\mathrm{O}_{2}{ }^{-}$at the biocompatible $\mathrm{pH}$ 6-7 through Equation (4):

$$
\mathrm{HO}_{2} \bullet \mathrm{H}^{+}+\mathrm{O}_{2}^{-} \quad \mathrm{pKa}=4.8
$$

In the presence of Fe-ions, the $\mathrm{HO}_{2}{ }^{\bullet}$ decomposes at much slower kinetics compared to the fast reaction between $\mathrm{O}_{2}{ }^{-}+\mathrm{Fe}^{3+}$, it is suggested to follow reactions (5) and (6) below:

$$
\begin{gathered}
\mathrm{HO}_{2}{ }^{\bullet}+\mathrm{Fe}^{3+} \rightarrow \mathrm{Fe}^{2+}+\mathrm{H}^{+}+\mathrm{O}_{2} \quad 3.3 \times 10^{5} \mathrm{M}^{-1} \mathrm{~s}^{-1} \\
\mathrm{O}^{2-}+\mathrm{Fe}^{3+} \rightarrow \mathrm{O}_{2}+\mathrm{Fe}^{2+} \quad 1.0 \times 10^{9} \mathrm{M}^{-1} \mathrm{~s}^{-1}
\end{gathered}
$$

The reaction between PE-FeOx and the bacteria cell wall involves diffusion of the metal-ions and absorption/translocation of the metal-ions on the bacterial cell bilayer. Electrostatic and Van der Waals interactions and controlled diffusion of $\mathrm{FeOx}$ at the interface with E. coli cells drive the interaction between the bacteria and the catalyst/photocatalyst surfaces [68].

\section{Coupling of $\mathrm{TiO}_{2}$ and Fe-Oxide: Innovative Preparation for Self-Sterilizing Surfaces}

Binary-oxides semiconductors due to their optical absorption and semiconductor behavior have been widely used for environmental decontamination purposes like $\mathrm{FeOx}-\mathrm{TiO}_{2}$. These binary oxides play an important role in pollutants and bacterial abatement involving redox processes [72,73]. Supported photocatalyst films, for self-cleaning and self-sterilizing purposes have recently been developed. This works involves the grafting of narrow band-gap semiconductors increase the light absorption in the visible region [68,72-76]. Work of this kind involves the selection of the meta/oxide components taking into consideration factors like (i) the surface spectral properties; (ii) the transients generated under femto-second laser pulses induced in the visible light region ( $545 \mathrm{~nm} / 25 \mathrm{fs}$ ); (iii) the bacterial inactivation kinetics of $E$. coli under low intensity solar/visible light and effect of different irradiation intensities and (iv) the mechanism of electron transfer from the FeOx used as photosensitizer to the low lying $\mathrm{TiO}_{2}$ trapping states as recently reported [73].

Femto-second ultra-fast kinetics is a powerful tool to detect and register the initial charge separation within very short times when $\mathrm{PE}-\mathrm{FeOx}-\mathrm{TiO}_{2}$ is irradiated under visible light [8]. Femto-second kinetics pulses in the visible range $(545 \mathrm{~nm} / 25 \mathrm{fs})$ to photo-induce and identify the short-lived transients. These transients are shown in Figure 5 at different pulse delay times as a function of wavelength $[73,75]$. FeOx absorbs laser pulses in the visible leading to the separation of the $\mathrm{cb}(\mathrm{e}-)$ and $\mathrm{vb}(\mathrm{h}+)$ or excited $\mathrm{d}-\mathrm{d}$ states. Figure 5 also shows that the spectral features are about the same for different delays. An increase in the pulse delay up to $500 \mathrm{ps}$, leads to a decrease in absorption bands. Additional experiments showed that the main part of the absorption amplitude at $600 \mathrm{~nm}$ 
decays within $25 \mathrm{ps}\left(\mathrm{t}_{\frac{1}{2}} \sim 25 \mathrm{ps}\right)$. Mid-gap Fe d-d states have been suggested as the main trapping sites with lifetimes of a few hundred picoseconds. The d-d states are ascribed to local excitons in the FeOx matrix [73]. In Figure 5, the electron trapping process was initiated at times of $150 \mathrm{fs}$ and compete with electron-hole recombination. The absorption band with a maximum at $600 \mathrm{~nm}$ was assigned to the $\mathrm{cb}(\mathrm{e}-)$ spectrum of the $\mathrm{FeOx}-\mathrm{TiO}_{2}$ i.e., an IFCT process occurring at the heterojunction $[75,76]$. These ultra short-lived transients in the visible region lead later to longer-lived intermediates in the minute range able to inactivate bacteria under band-gap continuous irradiation [73-75].

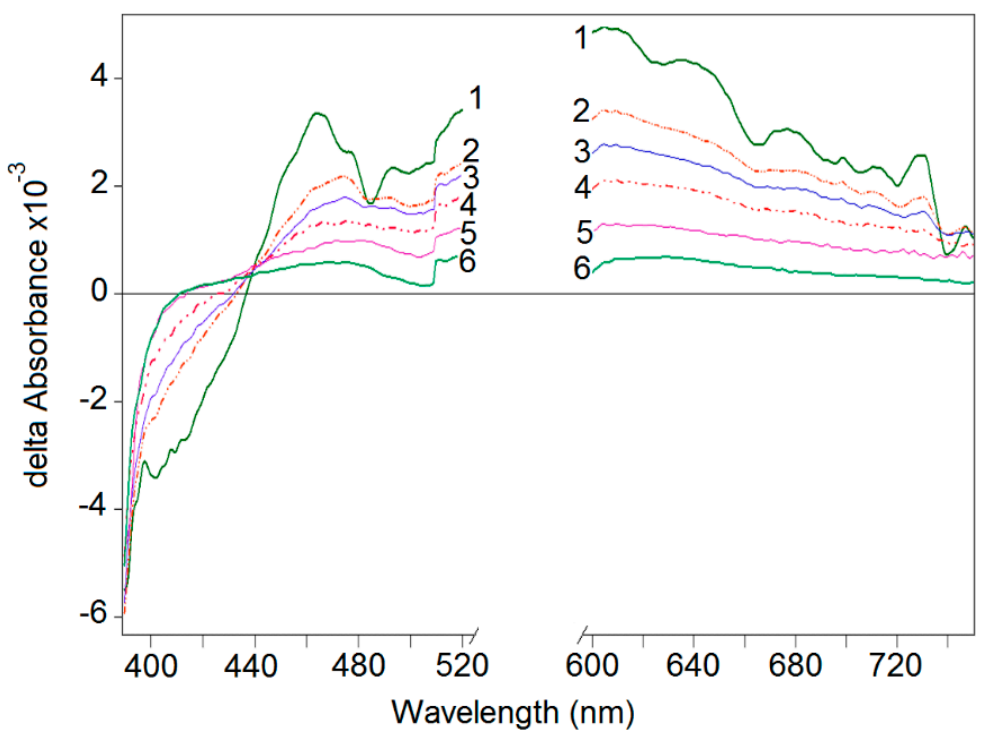

Figure 5. Transient spectra of the $\mathrm{FeOx}-\mathrm{TiO}_{2}-\mathrm{PE}$ as a function of wavelength after femtosecond laser pulse 25 fs (544 nm). Time delays: (1) 150 fs; (2) 500 fs; (3) 1 ps; (4) 3 ps; (5) 10 ps; (6) 500 ps [73].

\section{Conclusions}

The preparation of $\mathrm{TiO}_{2}, \mathrm{TiO}_{2}-\mathrm{TiO}_{2}, \mathrm{FeOx}$ and $\mathrm{FeOx}-\mathrm{TiO}_{2}$ thin films and their dynamics have been reviewed. The bacterial interactions with the film surface in the dark and under light conditions were discussed. The reactivity of $\mathrm{TiO}_{2}-\mathrm{Cu}$ towards bacteria seems to proceed through mechanisms that are still controversial. $\mathrm{TiO}_{2}-\mathrm{Cu}$ films obtained by sputtering were described as well as their surface properties. The mechanism of bacterial inactivation by $\mathrm{Cu}, \mathrm{TiO}_{2}$ and $\mathrm{FeOx}$ possibly involve an oligodynamic effect. Innovative PE-FeOx composites/coatings may have a potential application in disinfection for biomedical devices favored by the low Fe-cytotoxicity and high Fe-biocompatibility compared to heavy metals like $\mathrm{Ag}, \mathrm{Pt}$, and $\mathrm{Au}$. The co-sputtered $\mathrm{FeOx}-\mathrm{TiO}_{2}-\mathrm{PE}$ films show also a potential to improve the removal of pathogens and prevent biofilm formation under sun/visible light.

Acknowledgments: We thank the EPFL and Swiss National Science Foundation (SNF) Project (200021-143283/1) for financial support.

Conflicts of Interest: Authors declare no conflict of interest.

\section{References}

1. Soe, M.M.; Gould, C.V.; Pollock, D.; Edwards, J. Targeted Assessment for Prevention of Healthcare-Associated Infections: A New Prioritization Metric. Infect. Control Hosp. Epidemiol. 2015, 36, 12. [CrossRef] [PubMed]

2. Domek, M.J.; Chevalier, M.W.; Cameron, S.C.; McFeters, G.A. Evidence for the role of copper in the injury process of coliform bacteria in drinking water. Appl. Environ. Microbiol. 1984, 48, 289-293. [PubMed]

3. Noyce, J.O.; Michels, H.; Keevil, C.W. Potential use of copper surfaces to reduce survival of epidemic meticillin-resistant Staphylococcus aureus in the healthcare environment. J. Hosp. Infect. 2006, 63, 289-297. [CrossRef] [PubMed] 
4. Wilks, S.A.; Michels, H.; Keevil, C.W. The survival of Escherichia coli O157 on a range of metal surfaces. Int. J. Food Microbiol. 2005, 105, 445-454. [CrossRef] [PubMed]

5. Noimak, S.; Dunnill, Ch.; Wilson, M.; Parkin, I.P. The role of surfaces in catheter-associated infections. Chem. Soc. Rev. 2009, 38, 3435-3448. [CrossRef] [PubMed]

6. Thurman, R.B.; German, C.P. The molecular mechanisms of copper and silver ion disinfection of bacteria and viruses. Crit. Rev. Environ. Control 1989, 18, 259-315. [CrossRef]

7. Borkow, G.; Gabbay, J. Copper as abiocidal tool. Curr. Med. Chem. 2005, 12-13, 2163-2170. [CrossRef]

8. Page, K.; Wilson, M.; Parkin, I. Antimicrobial surfaces and their potential in reducing the role of the inanimate environment in the incidence of hospital-acquired infections. J. Mater. Chem. 2009, 19, 3818-3831. [CrossRef]

9. Monroe, D. Looking for chinks in the armor of bacterial biofilms. PLoS Biol. 2007, 5, e307. [CrossRef] [PubMed]

10. Haenle, M.; Fritshe, M.; Zietz, C.; Bader, R.; Heidenau, F. An extended spectrum bactericidal titanium dioxide $\left(\mathrm{TiO}_{2}\right)$ coating for metallic implants: In vitro effectiveness against MRSA and mechanical properties. J. Mater. Sci. 2011, 22, 381-387. [CrossRef] [PubMed]

11. Heidenau, F.; Mittelmeier, W.; Detsch, R.; Haenle, M.; Stenzel, F.; Ziegler, G.; Gollwitzer, H. A novel antibacterial Titania coating: Metal ion toxicity and in vitro surface colonization. J. Mater. Sci. 2005, 16, 883-889. [CrossRef] [PubMed]

12. Yates, H.M.; Brook, L.A.; Ditta, I.B.; Evans, P.; Foster, H.A.; Sheel, D.W.; Steele, A. Photo-induced self-cleaning and biocidal behviour of titania and copper oxide multilayers. J. Photochem. Photobiol. A 2008, 197, 187-205. [CrossRef]

13. Foster, H.A.; Sheel, P.; Sheel, W.D.; Evans, P.; Varghese, S.; Rutschke, N.; Yates, M.H. Antimicrobial activity of titatnia/silver and titania/copper films prepared by CVD. J. Photochem. Photobiol. A 2010, 216, 283-289. [CrossRef]

14. Frise, A.P. Choosing disinfectants. J. Hosp. Infect. 1999, 43, 255-264. [CrossRef]

15. Neely, A.N.; Maley, M.P. Survival of Enterococci and Staphylococci on Hospital Fabrics and Plastic. J. Clin. Microbiol. 2000, 38, 724-726. [PubMed]

16. Cohen, H.A.; Amir, J.; Matalon, A.; Mayan, R.; Beni, S.; Barzilai, A. Stethoscopes and otoscopes-a potential vector of infection? Fam. Pract. 1997, 14, 446-449. [CrossRef] [PubMed]

17. Boyce, J.; Potter-Bynoe, G.; Chevenert, C.; King, T. Environmental Contamination Due to Methicillin-Resistant Staphylococcus aureus Possible Infection Control Implications. Infect. Control Hosp. Epidemiol. 1997, 18, $622-627$. [CrossRef] [PubMed]

18. Bhalla, A.; Pultz, N.; Gries, D.; Ray, A.; Eckstein, E.; Aron, D.; Donskey, C. Acquisition of Nosocomial Pathogens on Hands after Contact With Environmental Surfaces Near Hospitalized Patients. Infect. Control Hosp. Epidemiol. 2004, 25, 164-167. [CrossRef] [PubMed]

19. Ding, X.; Liu, Z.; Su, J.; Yan, D. Human serum inhibits adhesion and biofilm formation in Candida albicans. BMC Microbiol. 2014, 14, 80. [CrossRef] [PubMed]

20. Vogt, S.; Kühn, K.-D.; Ege, W.; Pawlik, K.; Schnabelrauch, M. Novel Polylactide-Based Release Systems for Local Antibiotic Therapies. Materialwiss. Werkstofftech. 2003, 34, 1041-1047. [CrossRef]

21. Ginalska, G.; Osinska, M.; Uryniak, A.; Urbanik-Sypniewska, T.; Belcarz, A.; Rzeski, W.; Wolski, A. Antibacterial activity of gentamicin-bonded gelatin-sealed polyethylene terephthalate vascular prostheses. Eur. J. Vasc. Endovasc. Surg. 2005, 29, 419-424. [CrossRef] [PubMed]

22. Weaver, L.; Noyce, J.O.; Michels, H.T.; Keevil, C.W. Potential action of copper surfaces on meticillin-resistant Staphylococcus aureus. J. Appl. Microbiol. 2010, 109, 2200-2205. [CrossRef] [PubMed]

23. Torres, A.; Ruales, C.; Pulgarin, C.; Aimable, A.; Bowen, P.; Kiwi, J. Enhanced Inactivation of E. coli by RF-plasma Pretreated Cotton/CuO $\left(65 \mathrm{~m}^{2} / \mathrm{g}\right)$ under Visible Light. ACS Appl. Mater. Interfaces 2010, 2, 2547-2552. [CrossRef] [PubMed]

24. Rio, L.; Kusiak, E.; Kiwi, J.; Pulgarin, C.; Trampuz, A.; Bizini, A. Comparative methods to evaluate the bactericidal activity of copper-sputtered surfaces against methicillin-resistant Staphylococcus aureus. J. Appl. Microbiol. 2012, 78, 8176-8182. [CrossRef] [PubMed]

25. Mejia, M.I.; Restrepo, G.; Marin, J.M.; Sanjines, R.; Pulgarin, C.; Mielczarski, E.; Mielczarski, J.; Kiwi, J. Magnetron-Sputtered Ag-Modified Cotton Textiles Active in the Inactivation of Airborne Bacteria. ACS Appl. Mater. Interfaces 2010, 2, 230-235. [PubMed] 
26. Baghriche, O.; Kiwi, J.; Pulgarin, C.; Sanjines, R. Antibacterial Ag-ZrN surfaces promoted by subnanometric ZrN-clusters deposited by reactive pulsed magnetron sputtering. J. Photochem. Photobiol. A 2012, 229, 39. [CrossRef]

27. Polak, M.; Ohl, A.; Quaas, M.; Lukowski, G.; Lüthen, F.; Weltmann, K.-D.; Schröder, K. Oxygen and Water Plasma-Immersion Ion Implantation of Copper into Titanium for Antibacterial Surfaces of Medical Implants. Adv. Eng. Mater. 2010, 12, B511-B518. [CrossRef]

28. Finke, B.; Polak, M.; Hempel, F.; Schroeder, K.; Lukowski, G.; Müller, W.D.; Weltmann, K.D. Electrochemical Assessment of Cu-PIII Treated Titanium Samples for Antimicrobial Surfaces. Mater. Sci. Forum 2011, 706-709, 478-483. [CrossRef]

29. Ritmi, S.; Baghriche, O.; Sanjines, R.; Pulgarin, C.; Bensimon, M.; Lavanchy, J.-C.; Kiwi, J. Growth of TiO $2 / \mathrm{Cu}$ Films by HIPIMS for Accelerated Bacterial Loss of Viability. Surf. Coat. Technol. 2013, 232, 804. [CrossRef]

30. Baghriche, O.; Rtimi, S.; Pulgarin, C.; Sanjines, R.; Kiwi, J. Innovative $\mathrm{TiO}_{2} / \mathrm{Cu}$ surfaces inactivating bacteria $<5$ min under low intensity visible/actinic light. ACS Appl. Mater. Interfaces 2012, 4, 5234-5240. [PubMed]

31. Rtimi, S.; Sanjines, R.; Pulgarin, C.; Kiwi, J. Accelerated Esherichia coli inactivation in the Dark on Uniform Copper Flexible Surfaces. Biointerphases 2014, 9, 029012. [CrossRef] [PubMed]

32. Rtimi, S.; Ballo, M.; Pulgarin, C.; Entenza, J.; Bizzini, A.; Kiwi, J. Duality in the Escherichia coli and Methicillin Resistant Staphylococcus aureus Reduction Mechanism under Actinic Light on Innovative Co-sputtered Surfaces. Appl. Catal. A 2015, 498, 4185-4191. [CrossRef]

33. Rtimi, S.; Sanjines, R.; Pulgarin, C.; Kiwi, J. Quasi-Instantaneous Bacterial Inactivation on Cu-Ag Nano-particulate 3D-Catheters in the Dark and Under Light: Mechanism and Dynamics. ACS Appl. Mater. Interfaces 2016, 8, 47-55. [CrossRef] [PubMed]

34. Rtimi, S.; Sanjines, R.; Pulgarin, C.; Kiwi, J. Microstructure of Cu-Ag Uniform Nanoparticulate Films on Polyurethane 3D-catheters: Surface Properties. ACS Appl. Mater. Interfaces 2016, 8, 56-64. [CrossRef] [PubMed]

35. Rtimi, S.; Sanjines, R.; Andrzejczuk, M.; Pulgarin, C.; Kulik, A.; Kiwi, J. Innovative transparent non-scattering $\mathrm{TiO}_{2}$ bactericide thin films inducing increased E. coli cell wall fluidity. Surf. Coat. Technol. 2014, 254, 333-343. [CrossRef]

36. Zhang, H.; Liu, P.; Liu, X.; Zhang, S.; Yao, X.; An, T.; Amal, R.; Zhao, H. Fabrication of Highly Ordered $\mathrm{TiO}_{2}$ Nanorod/Nanotube Adjacent Arrays for Photo-electrochemical Applications. Langmuir 2010, 26, 11226-11232. [CrossRef] [PubMed]

37. Gunawan, C.; Teoh, W.Y.; Marquis, C.P.; Amal, R. Induced Adaptation of Bacillus sp. to Antimicrobial Nanosilver. Small 2013, 9, 3554-3560. [CrossRef] [PubMed]

38. Kramer, A.; Schwebke, I.; Kampf, G. How long do nosocomial pathogens pathogens persist on inanimate surfaces? A systematic reviews. BMC Infect. Dis. 2006, 6, 130-139. [CrossRef] [PubMed]

39. Dancer, S.J. The role of environmental cleaning in the control of hospital-acquired infections. J. Hosp. Infect. 2009, 73, 378-385. [CrossRef] [PubMed]

40. Rtimi, S.; Kiwi, J.; Pulgarin, C. Accelerated Antibacterial Inactivation on 2D Cu-Titania Surfaces: Latest Developments and Critical Issues. Coatings 2017, 7, 20. [CrossRef]

41. Rtimi, S.; Sanjines, R.; Pulgarin, C.; Kiwi, J. Effect of Light and Oxygen on repetitive bacterial inactivation on uniform, adhesive, robust and stable Cu-polyester surfaces. J. Adv. Oxid. Technol. 2017, 20, 20160178 . [CrossRef]

42. Rtimi, S.; Giannakis, S.; Bensimon, M.; Pulgarin, C.; Sanjines, R.; Kiwi, J. Supported $\mathrm{TiO}_{2}$ films deposited at different energies: Implications of the surface compactness on the catalytic kinetics. Appl. Catal. B 2016, 191, 42-52. [CrossRef]

43. Kelly, P.J.; Arnell, R.D. Magnetron sputtering: A review of recent developments and applications. Vacuum 2000, 65, 159-172. [CrossRef]

44. Farahani, N.; Kelly, P.J.; West, G.; Ratova, M.; Hill, C.; Vishnyakov, V. Photocatalytic activity of reactively sputtered and directly sputtered titania coatings. Thin Solid Films 2011, 520, 91464-91469. [CrossRef]

45. Ratova, M.; West, G.T.; Kelly, P.J. Optimisation of HIPIMS photocatalytic titania coatings for low temperature deposition. Surf. Coat. Technol. 2014, 250, 7-13. [CrossRef]

46. Fisher, L.; Ostovapour, S.; Kelly, P.; Whitehead, K.A.; Cooke, K.; Storgards, E.; Verran, J. Molybdenum doped titanium dioxide photocatalytic coatings for use as hygienic surfaces: The effect of soiling and antimicrobial activity. Biofouling 2014, 30, 911-919. [CrossRef] [PubMed] 
47. Qiu, X.; Miyauchi, M.; Sunada, K.; Minoshima, M.; Liu, M.; Lu, Y.; Li, D.; Shimodaira, Y.; Hosogi, Y.; Kuroda, Y.; et al. Hybrid CuxO/ $\mathrm{TiO}_{2}$ Nanocomposites As Risk-Reduction Materials in Indoor Environments. ACS Nano 2012, 6, 1609-1618. [CrossRef] [PubMed]

48. Sunada, K.; Watanabe, T.; Hashimoto, K. Bactericidal Activity of Copper-Deposited TiO 2 Thin Film under Weak UV Light Illumination. Environ. Sci. Technol. 2003, 37, 4785-4789. [CrossRef] [PubMed]

49. Zhang, L.; Dillert, R.; Bahnemann, D.; Vormoor, M. Photo-induced hydrophilicity and self-cleaning: Models and reality. Energy Environ. Sci. 2012, 5, 7491-7507. [CrossRef]

50. Rtimi, S.; Pulgarin, C.; Sanjines, R.; Kiwi, J. Innovative semi-transparent nanocomposite films presenting photo-switchable behavior and leading to a reduction of the risk of infection under sunlight. RSC Adv. 2013, 3, 16345-16348. [CrossRef]

51. Rtimi, S.; Baghriche, O.; Sanjines, R.; Pulgarin, C.; Bensimon, M.; Kiwi, J. TiON and TiON-Ag sputtered surfaces leading to bacterial inactivation under indoor actinic light. J. Photochem. Photobiol. A 2013, 256, 52-63. [CrossRef]

52. Rtimi, S.; Pulgarin, C.; Robyr, M.; Aybush, A.; Shelaev, I.; Gostev, F.; Nadtochenko, V.; Kiwi, J. Insight into the catalyst/photocatalyst microstructure presenting the same composition but leading to a variance in bacterial reduction under indoor visible light. Appl. Catal. B 2017, 208, 135-147. [CrossRef]

53. Rtimi, S.; Pascu, M.; Sanjines, R.; Pulgarin, C.; Ben-Simon, M.; Bouas, A.; Lavanchy, J.-C.; Kiwi, J. ZrNO-Ag co-sputtered surfaces leading to $E$. coli inactivation under actinic light: Evidence for the oligodynamic effect. Appl. Catal. B 2013, 138-139, 113-121. [CrossRef]

54. Rossnagel, S.; Hopwood, J. Magnetron sputter deposition with high levels of metal ionization. Appl. Phys. Lett. 1993, 63, 3285-3287. [CrossRef]

55. Ehasarian, P.A. High-power impulse magnetron sputtering and its applications. Pure Appl. Chem. 2010, 82, 1247-1258. [CrossRef]

56. Irie, H.; Kamiya, K.; Shibanuma, T.; Miura, S.; Tryck, D.; Yo koyama, T.; Hashimoto, K. Visible light sensitive $\mathrm{Cu}(\mathrm{II})$-grafted $\mathrm{TiO}_{2}$ photocatalysts: Activities and X-ray absorption fine structure analyses. J. Phys. Chem. C 2009, 113, 10671-10766. [CrossRef]

57. Irie, H.; Miura, S.; Kamiya, K.; Hashimoto, K. Efficient visible light-sensitive photocatalysts: Grafting Cu(II) onto $\mathrm{TiO}_{2}$ and $\mathrm{WO}_{3}$ photocatalysts. Chem. Phys. Lett. 2008, 457, 202-205. [CrossRef]

58. Ishiguro, H.; Yao, Y.; Nakano, R.; Hara, M.; Sunada, K.; Hashimoto, K.; Kajioka, J.; Fujishima, A.; Kubota, Y. Photocatalytic activity of $\mathrm{Cu}^{2+} / \mathrm{TiO}_{2}$-coated cordierite foam inactivates bacteriophages and Legionella pneumophila. Appl. Catal. B 2013, 129, 56-61. [CrossRef]

59. Rtimi, S.; Pulgarin, C.; Baghriche, O.; Kiwi, J. Accelerated inactivation obtained by HIPIMS sputtering on low cost surfaces with concomitant reduction in the metal-semiconductor content. RSC Adv. 2013, 3, 13127-13130. [CrossRef]

60. Mohapatr, M.; Anand, S. Synthesis and applications of nano-structured iron oxides/hydroxides-A review. Int. J. Eng. Sci. Technol. 2010, 2, 127-146. [CrossRef]

61. Fujishima, A.; Zhang, X.; Tryk, D.A. $\mathrm{TiO}_{2}$ photocatalysis and related surface phenomena. Surf. Sci. Rep. 2008, 63, 515-582. [CrossRef]

62. Daoud, W. Self-Cleaning Materials and Surfaces; John Wiley and Sons Ltd.: Chichester, UK, 2013.

63. Wu, W.; He, Q.; Jiang, C. Magnetic Iron Oxide Nanoparticles: Synthesis and Surface Functionalization Strategies. Nanoscale Res. Lett. 2008, 3, 397-415. [CrossRef] [PubMed]

64. Naka, K.; Narita, A.; Tanaka, H.; Chujo, Y.; Morita, M.; Inubushi, T.; Nishimura, I.; Hiruta, J.; Shibayama, H.; Koga, M.; et al. Biomedical applications of imidazolium cation-modified iron oxide nanoparticles. Polym. Adv. Technol. 2008, 19, 1421-1429. [CrossRef]

65. Levy, M.; Wilhelm, C.; Siaugue, J.-M.; Horner, O.; Bacri, J.-C.; Gazeau, F. Magnetically induced hyperthermia: Size-dependent heating power of $\gamma-\mathrm{Fe}_{2} \mathrm{O}_{3}$ nanoparticles. J. Phys. 2008, 20, 204133. [CrossRef] [PubMed]

66. Mukh-Qasem, R.; Gedanken, R. Sonochemical synthesis of stable hydrosol of $\mathrm{Fe}_{3} \mathrm{O}_{4}$ nanoparticles. J. Colloid Interface Sci. 2005, 284, 489-494. [CrossRef] [PubMed]

67. Zhou, L.; He, B.; Huang, J. One-Step Synthesis of Robust Amine- and Vinyl-Capped Magnetic Iron Oxide Nanoparticles for Polymer Grafting, Dye Adsorption, and Catalysis. ACS Appl. Mater. Interfaces 2013, 5, 8678-8685. [CrossRef] [PubMed]

68. Rtimi, S.; Pulgarin, C.; Sanjines, R.; Kiwi, J. Novel FeOx-polyethylene transparent films: Synthesis and mechanism of surface regeneration. RSC Adv. 2015, 5, 80203-80211. [CrossRef] 
69. Kever, K.; Imlay, J.A. Superoxide accelerates DNA damage by elevating free-iron levels. Proc. Natl. Acad. Sci. USA 1996, 93, 13635-13640.

70. Baghriche, O.; Rtimi, S.; Pulgarin, C.; Roussel, C.; Kiwi, J. RF-plasma pretreatment of surfaces leading to $\mathrm{TiO}_{2}$ coatings with improved optical absorption and OH-radical production. Appl. Catal. B 2013, 130-131, 65-72. [CrossRef]

71. Rtimi, S.; Gulin, A.; Sanjines, R.; Pulgarin, C.; Nadtochenko, V.; Kiwi, J. Innovative self-sterilizing transparent Fe-phosphate polyethylene films under visible light. RSC Adv. 2016, 6, 77066-77074. [CrossRef]

72. Rtimi, S.; Robyr, M.; Pulgarin, C.; Lavanchy, J.-C.; Kiwi, J. A New Perspective in the Use of FeOx-TiO Photocatalytic Films: Indole Degradation in the Absence of Fe-Leaching. J. Catal. 2016, 342, 184-192. [CrossRef]

73. Rtimi, S.; Sanjines, R.; Kiwi, J.; Pulgarin, C.; Bensimon, M.; Khmel, I.; Nadtochenko, V. Innovative photocatalyst $\left(\mathrm{FeOx}-\mathrm{TiO}_{2}\right)$ : Transients induced by Femtosecond laser leading to bacterial inactivation under visible light. RSC Adv. 2015, 5, 101751-101759. [CrossRef]

74. Rtimi, S. Indoor Light Enhanced Photocatalytic Ultra-Thin Films on Flexible Non-Heat Resistant Substrates Reducing Bacterial Infection Risks. Catalysts 2017, 7, 57. [CrossRef]

75. Rtimi, S.; Pulgarin, C.; Nadtochenko, V.A.; Gostev, F.E.; Shelaev, I.V.; Kiwi, J. FeOx-TiO 2 Film with Different Microstructures Leading to Femtosecond Transients with Different Properties: Biological Implications under Visible Light. Sci. Rep. 2016, 6, 30113. [CrossRef] [PubMed]

76. Rtimi, S.; Sanjines, R.; Pulgarin, C.; Houas, A.; Lavanchy, J.-C.; Kiwi, J. Coupling of narrow and wide band-gap semiconductors on uniform films active in bacterial disinfection under low intensity visible light: Implications of the interfacial charge transfer (IFCT). J. Hazard. Mater. 2013, 260, 860-868. [CrossRef] [PubMed]

(C) 2017 by the authors. Licensee MDPI, Basel, Switzerland. This article is an open access article distributed under the terms and conditions of the Creative Commons Attribution (CC BY) license (http:/ / creativecommons.org/licenses/by/4.0/). 